\title{
Use of Indigenous Knowledge to Adapt with Climate Change: A Case Study in An Giang Province, in the Mekong Delta, Viet Nam
}

\author{
PX Phu ${ }^{1 *}$, NN De ${ }^{2}$ and NTB Tran ${ }^{3}$ \\ ${ }^{1}$ An Giang University, Vietnam \\ ${ }^{2}$ CanTho University, Vietnam \\ ${ }^{3}$ An Giang University, Vietnam \\ *Corresponding author: PX Phu, An Giang University, Long Xuyen City, An Giang, Vietnam. \\ To Cite This Article: PX Phu, NN De, NTB Tran. Use of Indigenous Knowledge to Adapt with Climate Change: A Case Study in An Giang Province, \\ in the Mekong Delta, Viet Nam. Am J Biomed Sci \& Res. 2019 - 1(1). AJBSR.MS.ID.000506. DOI: 10.34297/AJBSR.2019.01.000506
}

Received 䀺: December 22, 2018; Published 眥: January 09, 2019

\begin{abstract}
This research was carried out to systematize and assess the appropriateness of farmer's indigenous knowledge and their adaptive capacity with floods. The research aimed at providing scientific foundation for proposing solutions to conserve and enhance the effectiveness of valuable indigenous knowledge in reducing vulnerability of people living in flooded areas. The results showed that local people are using several effective indigenous knowledge for coping with floods. However, the valuable indigenous knowledge has not recorded yet, nor documented in written materials for sharing to young generation and communities. Besides, some indigenous practices are not suitable in practice which required reevaluation for current flood adaptation strategies. The research suggested some solutions to conserve the most valuable indigenous knowledge for pro-active adaptation of local people in changing climate.
\end{abstract}

Keywords: Climate change; Indigenous knowledge; Flood; Adaptation

\section{Introduction}

The livelihood of rural people in the Mekong delta replies mainly on the local ecological system [1]. In recent years, the temperatures in inland Vietnam are rising and the weather become extreme and unpredictable [2]. In A Giang province, climate change has caused serious damages for the livelihood of local people such as flood, drought and forest fire [3]. In this case, indigenous knowledge, the knowledge gained over time through experience has been used to adapt with these changed [4,5]. This study therefore, aimed to get a deep for using of indigenous knowledge to adapt with climate change about how flood has affected the local people and the roles of indigenous knowledge in terms of building solutions to adapt with flood effects.

\section{Research objectives}

a. Systematize and evaluate the suitability of indigenous knowledge and the ability of farmers to adapt to floods in different conditions.

b. Propose conservative measures and promote the value of using indigenous knowledge of farmers in An Giang province.

\section{Research methods}

The information was collected by using a combination of quantitative and qualitative research methods. In particular, qualitative research methods including carrying out the evaluation with the participation of people and using the following tools such 
as Timeline; Seasonal Calendar; Venn Diagram; Problem Ranking Matrix; and detailed interviews of local leaders. Quantitative research methods are included interview local experienced households living with floods (around 180 households) in the upstream (Phu Huu commune), middle-stream (Vinh An commune) and downstream (Vinh Phuoc commune).

\section{Results and Discussion}

\section{Indigenous knowledge of the local people in flood forecasting}

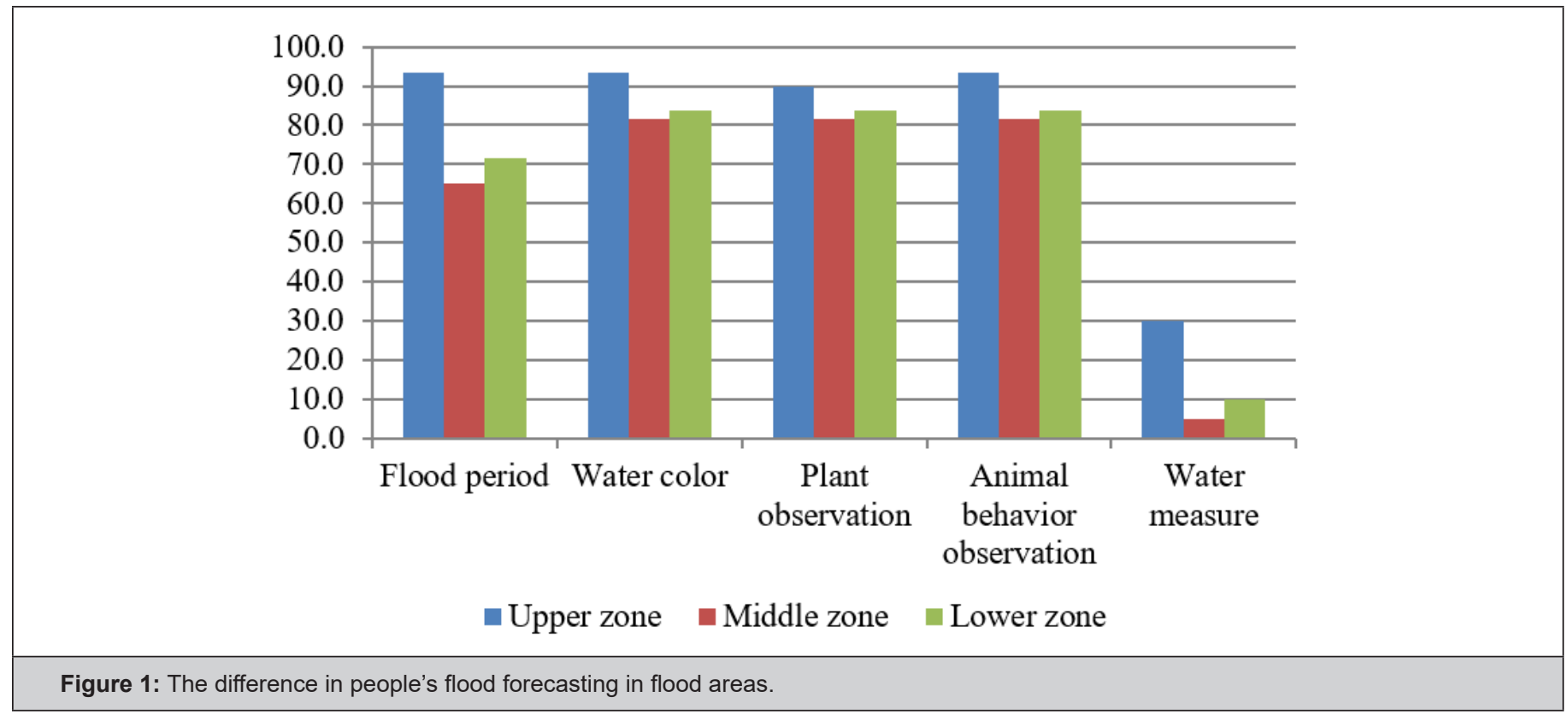

\begin{tabular}{|c|c|}
\hline Signs & Descriptions \\
\hline \multirow{3}{*}{ Flood period } & In May and July of the Lunar year, the water rises quickly; In July and August, flood starts. \\
\hline & Big flood takes place during Year of Dragon or October of Lunar year. \\
\hline & Every 3 year with small flood, 1 big flood will take place. \\
\hline \multirow{2}{*}{ Water color } & The water is red or dark. \\
\hline & More algae in water(water ovum) or water ovum appears early (In May, June of lunar year) \\
\hline \multirow{6}{*}{ Plant observation } & Reed shoots have 4-5 segments during Lunar May (2 segments indicate small flood) \\
\hline & Reed leaf tip has more than 2 segments. ( 1 segments indicate small flood) \\
\hline & Reed has $50 \mathrm{~cm}$ long segments. \\
\hline & Grass leaf grows near the tip or grows multiple segments. \\
\hline & Young bamboo shoot grows higher than older ones. \\
\hline & Elaeocarpus, hygrophilous roots grow more than usual. \\
\hline \multirow{3}{*}{ Animal behavior observation } & Bees, ants, termites, weavers nest on tall trees; rats burrow on high places. \\
\hline & Swallow, storks come in groups \\
\hline & Spider web appears more than usual in lunar July \\
\hline Water measure & $\begin{array}{c}\text { On December } 30 \text { of lunar year, people weigh a bottle of river water; On January 1, people get a different river } \\
\text { water bottle at the same position then weigh two bottles, big flood are about to take place if the later bottle is } \\
\text { heavier. }\end{array}$ \\
\hline
\end{tabular}

Household interview results (2016) showed that people used natural characteristics to predict flood. These experiences mainly passed on from generation to generation (Table 1). In addition, upstream communes seem to have more flood forecasting experience than midstream and downstream ones because floods occur earlier with higher vulnerability (Figure 1).

\section{Indigenous knowledge of the local people in weather forecasting}

Household interview results (2016) showed that upstream communes seem to have more weather forecasting experience than midstream and downstream ones (Table 2). 


\begin{tabular}{|c|c|}
\hline Signs & Descriptions \\
\hline \multirow{2}{*}{ Rain period change } & - Rains start in the beginning of lunar March or April. \\
\hline & - More rains take place during lunar June, July. \\
\hline Night sky observation & - Gloomy sky or less stars means rain the day after. \\
\hline \multirow{4}{*}{ Daytime sky observation } & - Windy and cloudy with thunderstorms \\
\hline & - Large pale blue clouds \\
\hline & - Heavy, soaked or black clouds with cold winds \\
\hline & - It was hot for several days \\
\hline \multirow{5}{*}{ Animal behavior observation } & - Dragonfly flying low means rain flying high means sun, flying in the middle means shady \\
\hline & - Ants stay higher place or move their nests and eggs to higher places. \\
\hline & - Winged ants appear, rains take place the day after. \\
\hline & - Termites appear, rains take place the day after. \\
\hline & - Flies and gadflies attack paddy fields, rains are about to take place. \\
\hline
\end{tabular}

Indigenous knowledge of the local to adapt to floods in agricultural production

Currently, due to unusual and complex weather, unpredictable nature so the accuracy of flood and weather prediction is no onger as high as before, in addition to the impact of science and technology, the number of people with indigenous knowledge is not many. Specifically, $89.4 \%$ of the interviewees said that the current flood situation is not predictable; $10.0 \%$ said that they change their predictions a little and only $13.3 \%$ said that the weather situation remains in their predictions (Figure 2).

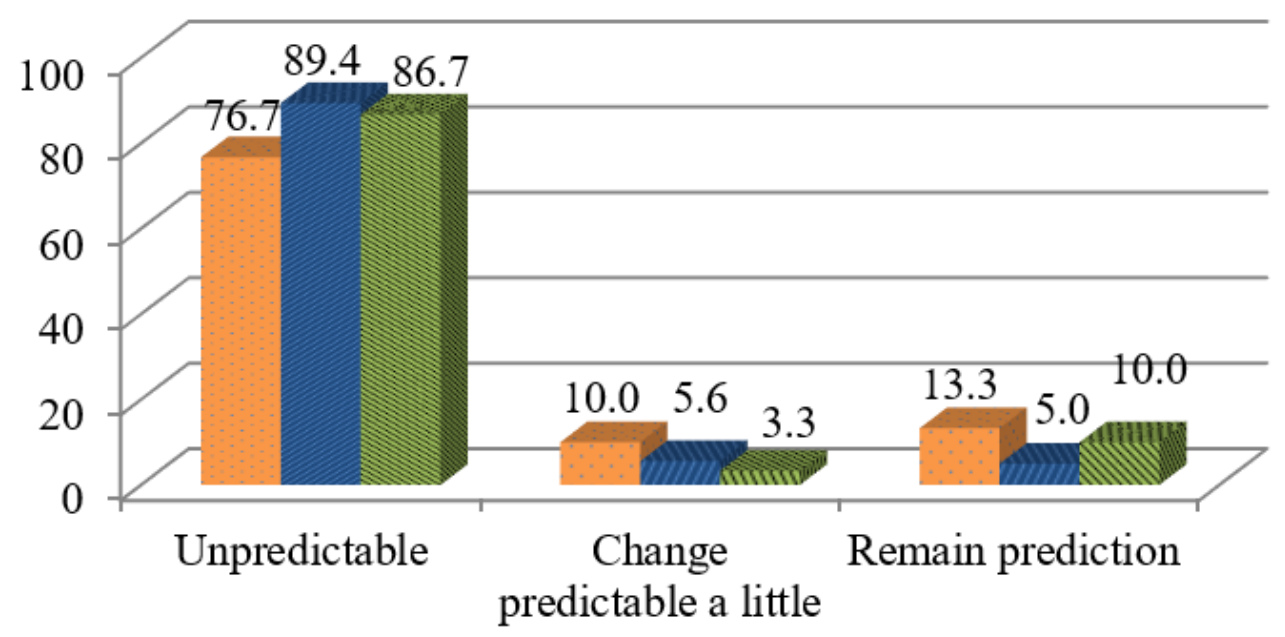

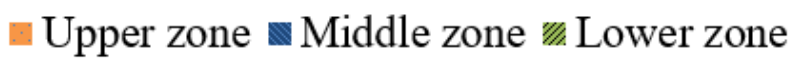

Figure 2: Assessing the accuracy of the predicted flood and weather local people.

\section{Conclusion}

Indigenous knowledge plays an important role in adapting to changes in the environment. As a national resource, it also contributes to the sustainable development of the local community in inexpensive ways, including the participation of people and achieving sustainable development. Much indigenous knowledge is valuable in predicting and adapting to floods. However, this knowledge has not been specifically recorded and stored appropriately for transmission to the latter and widely shared in the community. Indigenous knowledge of local people is based on the specific characteristics of the organisms and changes in environmental conditions such as warning signals for local people to forecast floods and weather to prepare for appropriate change in production and life. In addition, there is some indigenous knowledge that is no longer relevant and misleading compared to the present. It should be considered in the current context due to human impacts and climate change. Therefore, the possibility of flood forecast of the people also decreased, only a small number of people can predict the flood, the weather. It is necessary to increase knowledge and encourage people to combine indigenous knowledge and scientific knowledge to minimize the damage caused by floods. 


\section{References}

1. Judith Ehlert (2010) Living with flood local knowledge in the Mekong Delta, Vietnam. The University of Bonn, Germany.

2. Phu PX, Tran NT B (2017) Impact of aquatic resources on livelihood of the people Lower Mekong Basin- A case study in Phu Loc, Khanh An communes, Tan Chau, An Phu district, An Giang province. Journal of modern environmental science and engineering 3(11): 784-788.

3. Phu PX, Tran NTB (2014) Climate change impact on the vulnerability of livelihood in Lower Mekong Basin. Asia-Pacific Journal of Rural Development 24(1): 31-36.
4. Thong T, Helen James (2017) Transformation of household livelihoods in adapting to the impacts of flood control schemes in the Vietnamese Mekong Delta. Water resources \& rural development 9(2017): 67-80.

5. Warren DM (1991) Using Indigenous Knowledge in Agricultural Development; World Bank Discussion Paper No.127. Washington DC, USA. The World Bank. Read from Work bank report, 1998. Indigenous knowledge for development, Knowledge and Learning Center, Africa Region. 